\title{
Editorial
}

\section{Decision support systems in the Soviet Union}

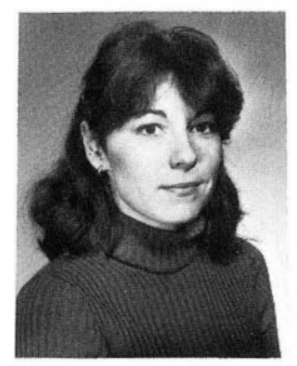

Celia Thomas is Assistant Professor of Economics at Appalachian State University, She holds a $\mathrm{Ph}$. D. in Economics from Duke University and a B.A. from the University of Virginia. She was previously a consultant with Charles River Associates in Boston. Dr. Thomas is co-editor of the forthcoming book, Optimization Models for Strategic Planning.

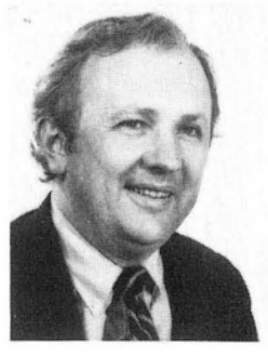

Thomas H. Naylor is Professor of Economics and Business Administration at the Fuqua School of Business at Duke University. $\mathrm{He}$ is also Director of the Center for Corporate Economics and Strategy at Duke and Managing Director of The Naylor Group, a management consulting group which specializes in strategic planning. He was the founder of SIMPLAN Systems, Inc., and served as its president for nine years.

His formal eduction includes a B.S. in Mathematics from Millsaps College, a B.S. in Industrial Engineering from Columbia University, an M.B.A. from Indiana University, and a Ph.D. in Economics from Tulane University.

Dr. Naylor has been a consultant to over 150 organizations throughout the world. Some of his clients have included IBM, AT \& T, Shell Oil, Squibb, The New York Times, Northwest Industries, and the Executive Office of the White House.

$\mathrm{He}$ is author or co-author of twenty books, including Corporate Planning Models (Addison-Wesley, 1979), Strategic Planning Management (Planning Executives Institute, 1980), and Managerial Economics (McGraw-Hill, 1982).

He has published 115 articles, which have appeared in professional journals such as Business Week, Long Range Planning, Planning Review, Managerial Planning, Management Science, Econometrica, Journal of the American Statistical Association, Economic Journal, Journal of Political Economy, Strategic Management Journal, and The New York Times.
Over the last decade, a number of economists and management scientists from the Soviet Union and Eastern Europe have visited the Center for Corporate Economics and Strategy at Duke University. They have reported on the increased use of computers as planning tools by GOSPLAN, the Soviet national planning agency, as well as academic research institutes and state-owned enterprises. The purpose of this essay is to review the experience with computer based planning models and decision support systems in the Soviet Union based in part on a recent visit to that country.

The use of computer based planning techniques in the Soviet Union goes back at least to the early 1960 s and is well documented in academic journals published in Russian and English. There appear to be three principal applications of computer based planning techniques in the Soviet Union: (1) techniques aimed simply at computerizing the arithmetic required to carry out centralized planning; (2) techniques oriented towards improving the efficiency of centralized planning; and (3) techniques associated with decentralized planning.

In the former case, computers are used to do the accounting and arithmetic necessary to support the entire Soviet centralized planning system. Much of this work is what one might call highvolume, routine data processing. However, a certain amount of computing is required to manipulate the Soviet input-output tables and to calculate estimates of equilibrium prices set by Soviet authorities.

The use of management science techniques to improve the efficiency of centralized planning goes back to 1938 and the work of L.V. Kantorovich, one of the originators of linear programming for which he received the Nobel Prize in economics. The so-called Liberman reforms of the 1960 s called

North-Holland

Human Systems Management 4 (1983) 61-63 
for the introduction of profits and incentives as instruments to improve the efficiency of centralized planning. Mathematical programming, control theory, and computer simulation models are among the tools used by Academician N.P. Fedorenko and his colleagues at the Central Economic-Mathematical Institute to increase the efficiency of centralized Soviet planning.

For several years there have been unpublished reports of increased interest among economists in the Soviet Union and other Comecon countries in decentralized planning, flexible prices and incentives. However, as a result of a recent trip to Moscow to observe the current status of this research, there is reason to believe it may have progressed much farther than was previously believed by American experts on Soviet affairs.

The visit to Moscow included interaction with management scientists, computer scientists, and economists in the leading research groups of the Soviet Academy of Sciences, GOSPLAN, and Moscow State University. They were using a wide variety of state-of-the-art management science and computer based modeling techniques including linear programming, input-output models, macroeconometric models, computer simulation, and controlled real world experiments with Soviet enterprises. The research agenda, however, was always the same: evaluating the effect of decentralized, market-driven planning on the Soviet economy. The quality of this research was at least equal to that being produced by leading European and American corporations and graduate schools of business. American politicians need not fear that Soviets will try to steal U.S. management science technology. They have already developed their own technology, and some of it could prove quite useful to American corporations.

GOSPLAN has developed macroeconometric models not only of the Soviet economy but also of the economy of the United States. One of the most interesting projects was a computer based management game to show the effects of flexible wages and incentives on workers' productivity and absenteeism. Another project involved real world experiments with a sample of Soviet industries to study the effects of alternative management systems and price-formation mechanisms on Soviet enterprises. Several groups were working with corporate simulation models. Since returning from Moscow, three other leading Soviet research groups outside of Moscow, and a Polish group, have contacted us about related projects.

These efforts appear to go well beyond the Liberman reforms of the 1960s. First, the work is widespread throughout the Soviet Union and other Eastern European countries, including Czechoslovakia, Hungary, Poland, and Yugoslavia. Second, this work is being done with the full knowledge of the Soviet government. Indeed, GOSPLAN is one of the sponsors of the work. To cynics who might claim that none of this is new, the answer is that it appears that someone in the Kremlin is listening to what the Soviet economists are saying. Maybe we should listen, too.

In spite of the fact that computer hardware in the Soviet Union appears to be five to ten years behind that of the United States, we found that the so-called 'decision support system' movement has already made its way to Moscow. Unfortunately, the Soviet definition of DSS appears to be almost as fuzzy as that set forth by Peter G.W. Keen and Michael Scott-Morton in their, book bearing that title. Although the Soviets expressed great interest in computer based planning software systems such as EXPRESS, IFPS, and SIMPLAN, we found no evidence of the existence of such software in Moscow. The reason for the absence of computer based planning software seems to be at least partially related to the fact that interactive computing in Moscow appears to be less developed than it is in the United States.

Of particular interest to the Soviets was the possibility of an exchange program involving chief executive officers of major American corporations and the heads of Soviet enterprises. They seemed to be interested in interacting with new corporate officials with fresh ideas who might spend less time trying to sell them something and more time trying to understand similarities and differences. This interest on the part of the Soviets was recently confirmed by the visit to Moscow of 250 senior executives of major American companies to discuss improved Soviet-American trade relations. Indeed, conversations with some of the executives who made that trip to Moscow indicate that the Kremlin is listening to what these Soviet economists have to say.

In spite of the temptation to do so, the West must avoid reading too much into these developments in the USSR. We are not suggesting that there are sweeping ideological changes on the 
horizon there. All of the economists whom we met in Moscow are loyal members of the Communist Party. They openly reject any notion of convergence between the Soviet and American economic systems. However, what can be said is that these economists are using sophisticated decision support systems to present their leaders with a menu of options for dealing with some very tough economic problems. There are new items on the menu, some of which are packaged more attractively than others.

Although strategic planning in the form that it is practiced in the United States does not appear to exist in the Soviet Union, Soviet management scientists have shown considerable interest in an approach to strategic planning used by Shell Oil, Federal Express, and Velsicol Chemical to deal with interdependent businesses. This approach to planning is known as the 'strategy matrix' and it attempts to facilitate the solution to a company's portfolio, investment, and business strategy selection problems.

One of the things that has hindered the development of strategic planning and decision support systems in the United States is the lack of a coherent theoretical framework to support each of these rapidly emerging fields. Soviet management scientists seem to recognize this problem as well. Wouldn't it be interesting if collaboration between Soviet and American management scientists and economists could lead to a theory of strategic planning and decision support systems in which decentralized, market-oriented planning, as well as centralized government planning, are viewed as two special cases of more generalized theory.

The Soviet Union has considerable experience with top-down, centralized government planning. Unfortunately, such planning has not solved all of the country's economic problems. The United States has a lot of experience with bottom-up, market-oriented planning. Just as top-down government planning has not proved to be a panacea for the Soviets, so the market does not seem to have solved all of our problems either. The two countries should spend more time listening to each other. We both stand to gain from the experience.

Thomas H. NAYLOR Celia THOMAS 